\title{
Pattern recognition receptors in GtoPdb v.2021.3
}

\author{
Clare Bryant ${ }^{1}$ and Tom P. Monie ${ }^{1}$
}

1. University of Cambridge, UK

\begin{abstract}
Pattern Recognition Receptors (PRRs, [104]) (nomenclature as agreed by NC-IUPHAR subcommittee on Pattern Recognition Receptors, [18]) participate in the innate immune response to microbial agents, the stimulation of which leads to activation of intracellular enzymes and regulation of gene transcription. PRRs express multiple leucine-rich regions to bind a range of microbiallyderived ligands, termed PAMPs or pathogen-associated molecular patterns or endogenous ligands, termed DAMPS or damage-associated molecular patterns. These include peptides, carbohydrates, peptidoglycans, lipoproteins, lipopolysaccharides, and nucleic acids. PRRs include both cell-surface and intracellular proteins. PRRs may be divided into signalling-associated members, identified here, and endocytic members, the function of which appears to be to recognise particular microbial motifs for subsequent cell attachment, internalisation and destruction. Some are involved in inflammasome formation, and modulation of IL- $1 \beta$ cleavage and secretion, and others in the initiation of the type I interferon response.
\end{abstract}

PRRs included in the Guide To PHARMACOLOGY are:

Catalytic PRRs (see links below this overview)

Toll-like receptors (TLRs)

Nucleotide-binding oligomerization domain, leucine-rich repeat containing receptors (NLRs, also known as NOD (Nucleotide oligomerisation domain)-like receptors)

RIG-I-like receptors (RLRs)

Caspase 4 and caspase 5

Non-catalytic PRRs

Absent in melanoma (AIM)-like receptors (ALRs)

C-type lectin-like receptors (CLRs)

Other pattern recognition receptors

Advanced glycosylation end-product specific receptor (RAGE)

\section{Contents}

This is a citation summary for Pattern recognition receptors in the Guide to Pharmacology database (GtoPdb). It exists purely as an adjunct to the database to facilitate the recognition of citations to and from the database by citation analyzers. Readers will almost certainly want to visit the relevant sections of the database which are given here under database links.

GtoPdb is an expert-driven guide to pharmacological targets and the substances that act on them. GtoPdb is a reference work which is most usefully represented as an on-line database. As in any publication this work should be appropriately cited, and the papers it cites should also be recognized. This document provides a citation for the relevant parts of the database, and also provides a reference list for the research cited by those parts. For further details see [19].

Please note that the database version for the citations given in GtoPdb are to the most recent preceding version in which the family or its subfamilies and targets were substantially changed. The links below are to the current version. If you need to consult the cited version, rather than the most recent version, please contact the GtoPdb curators.

\section{Database links}


Pattern recognition receptors

https://www.guidetopharmacology.org/GRAC/FamilyDisplayForward?familyId=302

Toll-like receptor family

https://www.guidetopharmacology.org/GRAC/FamilyDisplayForward?familyId=316

Receptors

TLR1

https://www.guidetopharmacology.org/GRAC/ObjectDisplayForward?objectId=1751

TLR2

https://www.guidetopharmacology.org/GRAC/ObjectDisplayForward?objectId=1752

TLR3

https://www.guidetopharmacology.org/GRAC/ObjectDisplayForward?objectId=1753

TLR4

https://www.guidetopharmacology.org/GRAC/ObjectDisplayForward?objectId=1754

TLR5

https://www.guidetopharmacology.org/GRAC/ObjectDisplayForward?objectId=1755

TLR6

https://www.guidetopharmacology.org/GRAC/ObjectDisplayForward?objectId=1756

TLR7

https://www.guidetopharmacology.org/GRAC/ObjectDisplayForward?objectId=1757

TLR8

https://www.guidetopharmacology.org/GRAC/ObjectDisplayForward?objectId=1758

TLR9

https://www.guidetopharmacology.org/GRAC/ObjectDisplayForward?objectId=1759

TLR10

https://www.guidetopharmacology.org/GRAC/ObjectDisplayForward?objectId=1760

TLR11

https://www.guidetopharmacology.org/GRAC/ObjectDisplayForward?objectId=1761

NOD-like receptor family

https://www.guidetopharmacology.org/GRAC/FamilyDisplayForward?familyId=317

Receptors

NOD1(nucleotide binding oligomerization domain containing 1)

https://www.guidetopharmacology.org/GRAC/ObjectDisplayForward?objectId=1762 NOD2(nucleotide binding oligomerization domain containing 2)

https://www.guidetopharmacology.org/GRAC/ObjectDisplayForward?objectId=1763 NLRC3

https://www.guidetopharmacology.org/GRAC/ObjectDisplayForward?objectId=1764 NLRC4

https://www.guidetopharmacology.org/GRAC/ObjectDisplayForward?objectId=1782 NLRC5

https://www.guidetopharmacology.org/GRAC/ObjectDisplayForward?objectId=1765 NLRX1

https://www.guidetopharmacology.org/GRAC/ObjectDisplayForward?objectId=1766 CIITA

https://www.guidetopharmacology.org/GRAC/ObjectDisplayForward?objectId=1767 NLRP1

https://www.guidetopharmacology.org/GRAC/ObjectDisplayForward?objectId=1768 NLRP2

https://www.guidetopharmacology.org/GRAC/ObjectDisplayForward?objectId=1769 NLRP3

https://www.guidetopharmacology.org/GRAC/ObjectDisplayForward?objectId=1770 NLRP4

https://www.guidetopharmacology.org/GRAC/ObjectDisplayForward?objectId=1771 NLRP5

https://www.guidetopharmacology.org/GRAC/ObjectDisplayForward?objectId=1772 NLRP6

https://www.guidetopharmacology.org/GRAC/ObjectDisplayForward?objectId=1773 NLRP7

https://www.guidetopharmacology.org/GRAC/ObjectDisplayForward?objectId=1774 NLRP8

https://www.guidetopharmacology.org/GRAC/ObjectDisplayForward?objectId=1775 NLRP9

https://www.guidetopharmacology.org/GRAC/ObjectDisplayForward?objectId=1776 NLRP10

https://www.guidetopharmacology.org/GRAC/ObjectDisplayForward?objectId=1777 NLRP11

https://www.guidetopharmacology.org/GRAC/ObjectDisplayForward?objectId=1778 NLRP12 
https://www.guidetopharmacology.org/GRAC/ObjectDisplayForward?objectId=1779 NLRP13

https://www.guidetopharmacology.org/GRAC/ObjectDisplayForward?objectId=1780 NLRP14

https://www.guidetopharmacology.org/GRAC/ObjectDisplayForward?objectId=1781 RIG-I-like receptor family

https://www.guidetopharmacology.org/GRAC/FamilyDisplayForward?familyId=940

Introduction to RIG-I-like receptor family

https://www.guidetopharmacology.org/GRAC/FamilyIntroductionForward?familyId=940

Receptors

RIG-1(DExD/H-box helicase 58)

https://www.guidetopharmacology.org/GRAC/ObjectDisplayForward?objectId=2920

MDA5(interferon induced with helicase $\mathrm{C}$ domain 1)

https://www.guidetopharmacology.org/GRAC/ObjectDisplayForward?objectId=2921

LGP2(DExH-box helicase 58)

https://www.guidetopharmacology.org/GRAC/ObjectDisplayForward?objectId=2922

\section{References}

1. (2006) CpG 7909: PF 3512676, PF-3512676. Drugs R D 7: 312-6 [PMID:16922592]

2. Adams JL, Smothers J, Srinivasan R and Hoos A. (2015) Big opportunities for small molecules in immuno-oncology. Nat Rev Drug Discov 14: 603-22 [PMID:26228631]

3. Ahlers LR and Goodman AG. (2016) Nucleic acid sensing and innate immunity: signaling pathways controlling viral pathogenesis and autoimmunity. Curr Clin Microbiol Rep 3: 132-141 [PMID:27857881]

4. Akira S and Takeda K. (2004) Toll-like receptor signalling. Nat Rev Immunol 4: 499-511 [PMID:15229469]

5. Akiyama M, Takeichi T, McGrath JA and Sugiura K. (2017) Autoinflammatory keratinization diseases. J Allergy Clin Immunol 140: 1545-1547 [PMID:28668225]

6. Alexopoulou L, Holt AC, Medzhitov R and Flavell RA. (2001) Recognition of double-stranded RNA and activation of NF-kappaB by Toll-like receptor 3. Nature 413: 732-8 [PMID:11607032]

7. Babdor J, Descamps D, Adiko AC, Tohmé M, Maschalidi S, Evnouchidou I, Vasconcellos LR, De Luca M, Mauvais FX and Garfa-Traore $\mathrm{M}$ et al.. (2017) IRAP ${ }^{+}$endosomes restrict TLR9 activation and signaling. Nat Immunol 18: 509-518 [PMID:28319098]

8. Baldwin AG, Brough D and Freeman S. (2016) Inhibiting the Inflammasome: A Chemical Perspective. J Med Chem 59: 1691-710 [PMID:26422006]

9. Baldwin AG, Rivers-Auty J, Daniels MJD, White CS, Schwalbe CH, Schilling T, Hammadi H, Jaiyong P, Spencer NG and England H et al.. (2017) Boron-Based Inhibitors of the NLRP3 Inflammasome. Cell Chem Biol 24: 1321-1335.e5 [PMID:28943355]

10. Barochia A, Solomon S, Cui X, Natanson C and Eichacker PQ. (2011) Eritoran tetrasodium (E5564) treatment for sepsis: review of preclinical and clinical studies. Expert Opin Drug Metab Toxicol 7: 479-94 [PMID:21323610]

11. Bazin HG, Murray TJ, Bowen WS, Mozaffarian A, Fling SP, Bess LS, Livesay MT, Arnold JS, Johnson CL and Ryter KT et al.. (2008) The 'Ethereal' nature of TLR4 agonism and antagonism in the AGP class of lipid A mimetics. Bioorg Med Chem Lett 18: 5350-4 [PMID:18835160]

12. Beutler B, Du X and Poltorak A. (2001) Identification of Toll-like receptor 4 (Tlr4) as the sole conduit for LPS signal transduction: genetic and evolutionary studies. $J$ Endotoxin Res 7: 277-80 [PMID:11717581]

13. Biggadike K, Ahmed M, Ball DI, Coe DM, Dalmas Wilk DA, Edwards CD, Gibbon BH, Hardy CJ, Hermitage SA and Hessey JO et al.. (2016) Discovery of 6-Amino-2-\{[(1S)-1-methylbutyl]oxy $\}-9$ [5-(1-piperidinyl)pentyl]-7,9-dihydro-8H-purin-8-one (GSK2245035), a Highly Potent and Selective Intranasal Toll-Like Receptor 7 Agonist for the Treatment of Asthma. J Med Chem 59: 1711-26 [PMID:26861551]

14. Bleda S and de Haro J. (2018) Identification of a potential inhibitor of NLRP1 inflammasome for the treatment of peripheral arterial disease. Int J Cardiol 256: 30 [PMID:29454411]

15. Bleda S, de Haro J, Varela C, Ferruelo A and Acin F. (2016) Elevated levels of triglycerides and vldl-cholesterol provoke activation of nlrp1 inflammasome in endothelial cells. Int J Cardiol 220: 52-5 [PMID:27372042]

16. Bou Karroum N, Moarbess G, Guichou JF, Bonnet PA, Patinote C, Bouharoun-Tayoun H, Chamat S, Cuq P, Diab-Assaf M and Kassab I et al.. (2019) Novel and Selective TLR7 Antagonists among the Imidazo[1,2-a]pyrazines, Imidazo[1,5- $a$ ]quinoxalines, and Pyrazolo[1,5- $a$ ]quinoxalines Series. J Med Chem 62: 7015-7031 [PMID:31283223]

17. Bruns AM and Horvath CM. (2014) Antiviral RNA recognition and assembly by RLR family innate immune sensors. Cytokine Growth Factor Rev 25: 507-12 [PMID:25081315]

18. Bryant CE, Orr S, Ferguson B, Symmons MF, Boyle JP and Monie TP. (2015) International Union 
of Basic and Clinical Pharmacology. XCVI. Pattern recognition receptors in health and disease. Pharmacol Rev 67: 462-504 [PMID:25829385]

19. Buneman P, Christie G, Davies JA, Dimitrellou R, Harding SD, Pawson AJ, Sharman JL and Wu Y. (2020) Why data citation isn't working, and what to do about it Database 2020 [PMID:32367113]

20. Buschow SI, Biesta PJ, Groothuismink ZMA, Erler NS, Vanwolleghem T, Ho E, Najera I, AitGoughoulte M, de Knegt RJ and Boonstra A et al.. (2018) TLR7 polymorphism, sex and chronic HBV infection influence plasmacytoid DC maturation by TLR7 ligands. Antiviral Res 157: 27-37 [PMID:29964062]

21. Chamaillard M, Girardin SE, Viala J and Philpott DJ. (2003) Nods, Nalps and Naip: intracellular regulators of bacterial-induced inflammation. Cell Microbiol 5: 581-92 [PMID:12925128]

22. Chan M, Hayashi T, Mathewson RD, Nour A, Hayashi Y, Yao S, Tawatao RI, Crain B, Tsigelny IF and Kouznetsova VL et al.. (2013) Identification of substituted pyrimido[5,4-b]indoles as selective Toll-like receptor 4 ligands. J Med Chem 56: 4206-23 [PMID:23656327]

23. Chavarría-Smith J and Vance RE. (2015) The NLRP1 inflammasomes. Immunol Rev 265: 22-34 [PMID:25879281]

24. Coll RC, Robertson AA, Chae JJ, Higgins SC, Muñoz-Planillo R, Inserra MC, Vetter I, Dungan LS, Monks BG and Stutz A et al.. (2015) A small-molecule inhibitor of the NLRP3 inflammasome for the treatment of inflammatory diseases. Nat Med 21: 248-55 [PMID:25686105]

25. Cui J, Zhu L, Xia X, Wang HY, Legras X, Hong J, Ji J, Shen P, Zheng S and Chen ZJ et al.. (2010) NLRC5 negatively regulates the NF-kappaB and type I interferon signaling pathways. Cell 141: 483-96 [PMID:20434986]

26. Davis BK, Wen H and Ting JP. (2011) The inflammasome NLRs in immunity, inflammation, and associated diseases. Annu Rev Immunol 29: 707-35 [PMID:21219188]

27. Dellacasagrande J. (2011) Humanised antibodies to toll-like receptor 2 and uses thereof Patent number: WO2011003925.

28. Dodé C, Le Dû N, Cuisset L, Letourneur F, Berthelot JM, Vaudour G, Meyrier A, Watts RA, Scott DG and Nicholls A et al.. (2002) New mutations of CIAS1 that are responsible for Muckle-Wells syndrome and familial cold urticaria: a novel mutation underlies both syndromes. Am J Hum Genet 70: 1498-506 [PMID:11992256]

29. Farhat K, Riekenberg S, Heine H, Debarry J, Lang R, Mages J, Buwitt-Beckmann U, Röschmann $\mathrm{K}$, Jung G and Wiesmüller KH et al.. (2008) Heterodimerization of TLR2 with TLR1 or TLR6 expands the ligand spectrum but does not lead to differential signaling. J Leukoc Biol 83: 692701 [PMID:18056480]

30. Fitzgerald KA and Kagan JC. (2020) Toll-like Receptors and the Control of Immunity. Cell 180: 1044-1066 [PMID:32164908]

31. Garay RP, Viens P, Bauer J, Normier G, Bardou M, Jeannin JF and Chiavaroli C. (2007) Cancer relapse under chemotherapy: why TLR2/4 receptor agonists can help. Eur J Pharmacol 563: 117 [PMID:17383632]

32. Glick G, Ghosh S, Roush WR, Olhava EJ and O'Malley D. (2018) Substituted imidazo-quinolines as nlrp3 modulators Patent number: WO2018152396A1.

33. Grandemange S, Sanchez E, Louis-Plence P, Tran Mau-Them F, Bessis D, Coubes C, Frouin E, Seyger M, Girard M and Puechberty J et al.. (2017) A new autoinflammatory and autoimmune syndrome associated with NLRP1 mutations: NAIAD (NLRP1-associated autoinflammation with arthritis and dyskeratosis). Ann Rheum Dis 76: 1191-1198 [PMID:27965258]

34. Harton JA and Ting JP. (2000) Class II transactivator: mastering the art of major histocompatibility complex expression. Mol Cell Biol 20: 6185-94 [PMID:10938095]

35. Hayashi F, Smith KD, Ozinsky A, Hawn TR, Yi EC, Goodlett DR, Eng JK, Akira S, Underhill DM and Aderem A. (2001) The innate immune response to bacterial flagellin is mediated by Toll-like receptor 5. Nature 410: 1099-103 [PMID:11323673]

36. Heil F, Ahmad-Nejad P, Hemmi H, Hochrein H, Ampenberger F, Gellert T, Dietrich H, Lipford G, Takeda K and Akira S et al.. (2003) The Toll-like receptor 7 (TLR7)-specific stimulus loxoribine uncovers a strong relationship within the TLR7, 8 and 9 subfamily. Eur J Immunol 33: 2987-97 [PMID:14579267]

37. Hemmi H, Kaisho T, Takeuchi O, Sato S, Sanjo H, Hoshino K, Horiuchi T, Tomizawa H, Takeda K and Akira S. (2002) Small anti-viral compounds activate immune cells via the TLR7 MyD88dependent signaling pathway. Nat Immunol 3: 196-200 [PMID:11812998]

38. Hemmi H, Takeuchi O, Kawai T, Kaisho T, Sato S, Sanjo H, Matsumoto M, Hoshino K, Wagner H and Takeda K et al.. (2000) A Toll-like receptor recognizes bacterial DNA. Nature 408: 740-5 [PMID:11130078]

39. Henao-Mejia J, Elinav E, Jin C, Hao L, Mehal WZ, Strowig T, Thaiss CA, Kau AL, Eisenbarth SC and Jurczak MJ et al.. (2012) Inflammasome-mediated dysbiosis regulates progression of NAFLD and obesity. Nature 482: 179-85 [PMID:22297845]

40. Henmyr V, Carlberg D, Manderstedt E, Lind-Halldén C, Säll T, Cardell LO and Halldén C. (2017) Genetic variation of the Toll-like receptors in a Swedish allergic rhinitis case population. BMC 
Med Genet 18: 18 [PMID:28228119]

41. Hoffman HM, Mueller JL, Broide DH, Wanderer AA and Kolodner RD. (2001) Mutation of a new gene encoding a putative pyrin-like protein causes familial cold autoinflammatory syndrome and Muckle-Wells syndrome. Nat Genet 29: 301-5 [PMID:11687797]

42. Hozumi H, Fujisawa T, Nakashima R, Johkoh T, Sumikawa H, Murakami A, Enomoto N, Inui N, Nakamura Y and Hosono Y et al.. (2016) Comprehensive assessment of myositis-specific autoantibodies in polymyositis/dermatomyositis-associated interstitial lung disease. Respir Med 121: 91-99 [PMID:27888997]

43. Huynh AS, Chung WJ, Cho HI, Moberg VE, Celis E, Morse DL and Vagner J. (2012) Novel tolllike receptor 2 ligands for targeted pancreatic cancer imaging and immunotherapy. J Med Chem 55: 9751-62 [PMID:23098072]

44. Ii M, Matsunaga N, Hazeki K, Nakamura K, Takashima K, Seya T, Hazeki O, Kitazaki T and Iizawa Y. (2006) A novel cyclohexene derivative, ethyl (6R)-6-[N-(2-Chloro-4-

fluorophenyl)sulfamoyl]cyclohex-1-ene-1-carboxylate (TAK-242), selectively inhibits toll-like receptor 4-mediated cytokine production through suppression of intracellular signaling. Mol Pharmacol 69: 1288-95 [PMID:16373689]

45. Imamura R, Wang Y, Kinoshita T, Suzuki M, Noda T, Sagara J, Taniguchi S, Okamoto H and Suda T. (2010) Anti-inflammatory activity of PYNOD and its mechanism in humans and mice. $J$ Immunol 184: 5874-84 [PMID:20393137]

46. Ingalls RR, Monks BG, Savedra R, Christ WJ, Delude RL, Medvedev AE, Espevik T and Golenbock DT. (1998) CD11/CD18 and CD14 share a common lipid A signaling pathway. $J$ Immunol 161: 5413-20 [PMID:9820516]

47. Ising C, Venegas C, Zhang S, Scheiblich H, Schmidt SV, Vieira-Saecker A, Schwartz S, Albasset S, McManus RM and Tejera D et al.. (2019) NLRP3 inflammasome activation drives tau pathology. Nature 575: 669-673 [PMID:31748742]

48. Jeong E and Lee JY. (2011) Intrinsic and extrinsic regulation of innate immune receptors. Yonsei Med J 52: 379-92 [PMID:21488180]

49. Jerala R. (2007) Structural biology of the LPS recognition. Int J Med Microbiol 297: 353-63 [PMID:17481951]

50. Jiang H, He H, Chen Y, Huang W, Cheng J, Ye J, Wang A, Tao J, Wang C and Liu Q et al.. (2017) Identification of a selective and direct NLRP3 inhibitor to treat inflammatory disorders. $J$ Exp Med 214: 3219-3238 [PMID:29021150]

51. Jurk M, Heil F, Vollmer J, Schetter C, Krieg AM, Wagner H, Lipford G and Bauer S. (2002) Human TLR7 or TLR8 independently confer responsiveness to the antiviral compound R-848. Nat Immunol 3: 499 [PMID:12032557]

52. Karki R, Man SM and Kanneganti TD. (2017) Inflammasomes and Cancer. Cancer Immunol Res 5: 94-99 [PMID:28093447]

53. Kawai T and Akira S. (2007) Antiviral signaling through pattern recognition receptors. $J$ Biochem 141: 137-45 [PMID:17190786]

54. Kawasaki K, Akashi S, Shimazu R, Yoshida T, Miyake K and Nishijima M. (2000) Mouse toll-like receptor 4.MD-2 complex mediates lipopolysaccharide-mimetic signal transduction by Taxol. $J$ Biol Chem 275: 2251-4 [PMID:10644670]

55. Khan PM, Correa RG, Divlianska DB, Peddibhotla S, Sessions EH, Magnuson G, Brown B, Suyama E, Yuan H and Mangravita-Novo A et al.. (2011) Identification of Inhibitors of NOD1Induced Nuclear Factor-kB Activation. ACS Med Chem Lett 2: 780-785 [PMID:22003428]

56. Kuenzel S, Till A, Winkler M, Häsler R, Lipinski S, Jung S, Grötzinger J, Fickenscher H, Schreiber S and Rosenstiel P. (2010) The nucleotide-binding oligomerization domain-like receptor NLRC5 is involved in IFN-dependent antiviral immune responses. J Immunol 184: 1990-2000 [PMID:20061403]

57. Lamphier M, Zheng W, Latz E, Spyvee M, Hansen H, Rose J, Genest M, Yang H, Shaffer C and Zhao Y et al.. (2014) Novel small molecule inhibitors of TLR7 and TLR9: mechanism of action and efficacy in vivo. Mol Pharmacol 85: 429-40 [PMID:24342772]

58. Larson P, Kucaba TA, Xiong Z, Olin M, Griffith TS and Ferguson DM. (2017) Design and Synthesis of N1-Modified Imidazoquinoline Agonists for Selective Activation of Toll-like Receptors 7 and 8. ACS Med Chem Lett 8: 1148-1152 [PMID:29152046]

59. LeibundGut-Landmann S, Waldburger JM, Krawczyk M, Otten LA, Suter T, Fontana A, AchaOrbea H and Reith W. (2004) Mini-review: Specificity and expression of CIITA, the master regulator of MHC class II genes. Eur J Immunol 34: 1513-25 [PMID:15162420]

60. Li L, Liu X, Sanders KL, Edwards JL, Ye J, Si F, Gao A, Huang L, Hsueh EC and Ford DA et al.. (2019) TLR8-Mediated Metabolic Control of Human Treg Function: A Mechanistic Target for Cancer Immunotherapy. Cell Metab 29: 103-123.e5 [PMID:30344014]

61. Li L, Yu H, Jiang Y, Deng B, Bai L, Kijlstra A and Yang P. (2016) Genetic Variations of NLR family genes in Behcet's Disease. Sci Rep 6: 20098 [PMID:26833430]

62. Liu Y, Olagnier D and Lin R. (2016) Host and Viral Modulation of RIG-I-Mediated Antiviral Immunity. Front Immunol 7: 662 [PMID:28096803] 
63. Liu YR, Yan X, Yu HX, Yao Y, Wang JQ, Li XF, Chen RN, Xu QQ, Ma TT and Huang C et al.. (2017) NLRC5 promotes cell proliferation via regulating the NF-kB signaling pathway in Rheumatoid arthritis. Mol Immunol 91: 24-34 [PMID:28865311]

64. Lu H, Dietsch GN, Matthews MA, Yang Y, Ghanekar S, Inokuma M, Suni M, Maino VC, Henderson KE and Howbert JJ et al.. (2012) VTX-2337 is a novel TLR8 agonist that activates NK cells and augments ADCC. Clin Cancer Res 18: 499-509 [PMID:22128302]

65. Lucas K and Maes M. (2013) Role of the Toll Like receptor (TLR) radical cycle in chronic inflammation: possible treatments targeting the TLR4 pathway. Mol Neurobiol 48: 190-204 [PMID:23436141]

66. Mach B, Steimle V and Reith W. (1994) MHC class II-deficient combined immunodeficiency: a disease of gene regulation. Immunol Rev 138: 207-21 [PMID:8070816]

67. Mackman RL, Mish M, Chin G, Perry JK, Appleby T, Aktoudianakis V, Metobo S, Pyun P, Niu C and Daffis S et al.. (2020) Discovery of GS-9688 (Selgantolimod) as a Potent and Selective Oral Toll-Like Receptor 8 Agonist for the Treatment of Chronic Hepatitis B. J Med Chem 63: 1018810203 [PMID:32407112]

68. Mangan MS and Latz E. (2014) NLRC3 puts the brakes on STING. Immunity 40: 305-6 [PMID:24656040]

69. Mangan MSJ, Olhava EJ, Roush WR, Seidel HM, Glick GD and Latz E. (2018) Targeting the NLRP3 inflammasome in inflammatory diseases. Nat Rev Drug Discov 17: 688 [PMID:30116046]

70. Mangan MSJ, Olhava EJ, Roush WR, Seidel HM, Glick GD and Latz E. (2018) Targeting the NLRP3 inflammasome in inflammatory diseases. Nat Rev Drug Discov 17: 588-606 [PMID:30026524]

71. Marchetti C, Swartzwelter B, Gamboni F, Neff CP, Richter K, Azam T, Carta S, Tengesdal I, Nemkov T and D'Alessandro A et al.. (2018) OLT1177, a $\beta$-sulfonyl nitrile compound, safe in humans, inhibits the NLRP3 inflammasome and reverses the metabolic cost of inflammation. Proc Natl Acad Sci USA 115: E1530-E1539 [PMID:29378952]

72. Martinon F, Pétrilli V, Mayor A, Tardivel A and Tschopp J. (2006) Gout-associated uric acid crystals activate the NALP3 inflammasome. Nature 440: 237-41 [PMID:16407889]

73. Matsumiya T and Stafforini DM. (2010) Function and regulation of retinoic acid-inducible geneI. Crit Rev Immunol 30: 489-513 [PMID:21175414]

74. Maver A, Lavtar P, Ristić S, Stopinšek S, Simčič S, Hočevar K, Sepčić J, Drulović J, Pekmezović T and Novaković I et al.. (2017) Identification of rare genetic variation of NLRP1 gene in familial multiple sclerosis. Sci Rep 7: 3715 [PMID:28623311]

75. Meier A, Chang JJ, Chan ES, Pollard RB, Sidhu HK, Kulkarni S, Wen TF, Lindsay RJ, Orellana L and Mildvan D et al.. (2009) Sex differences in the Toll-like receptor-mediated response of plasmacytoid dendritic cells to HIV-1. Nat Med 15: 955-9 [PMID:19597505]

76. Miao EA, Andersen-Nissen E, Warren SE and Aderem A. (2007) TLR5 and Ipaf: dual sensors of bacterial flagellin in the innate immune system. Semin Immunopathol 29: 275-88 [PMID:17690885]

77. Milam EC, Futran J and Franks Jr AG. (2016) Anti-MDA5 Antibody Dermatomyositis Overlap with Systemic Lupus Erythematosus: A Case Report and Review of the Literature. Open Rheumatol J 10: 122-128 [PMID:28077979]

78. Morin MD, Wang Y, Jones BT, Mifune Y, Su L, Shi H, Moresco EMY, Zhang H, Beutler B and Boger DL. (2018) Diprovocims: A New and Exceptionally Potent Class of Toll-like Receptor Agonists. J Am Chem Soc 140: 14440-14454 [PMID:30272974]

79. Nakamura T, Wada H, Kurebayashi H, McInally T, Bonnert R and Isobe Y. (2013) Synthesis and evaluation of 8-oxoadenine derivatives as potent Toll-like receptor 7 agonists with high water solubility. Bioorg Med Chem Lett 23: 669-72 [PMID:23265901]

80. Nakao Y, Funami K, Kikkawa S, Taniguchi M, Nishiguchi M, Fukumori Y, Seya T and Matsumoto M. (2005) Surface-expressed TLR6 participates in the recognition of diacylated lipopeptide and peptidoglycan in human cells. J Immunol 174: 1566-73 [PMID:15661917]

81. Neerincx A, Lautz K, Menning M, Kremmer E, Zigrino P, Hösel M, Büning H, Schwarzenbacher $\mathrm{R}$ and Kufer TA. (2010) A role for the human nucleotide-binding domain, leucine-rich repeatcontaining family member NLRC5 in antiviral responses. J Biol Chem 285: 26223-32 [PMID:20538593]

82. Oh DY, Baumann K, Hamouda O, Eckert JK, Neumann K, Kücherer C, Bartmeyer B, Poggensee G, Oh N and Pruss A et al.. (2009) A frequent functional toll-like receptor 7 polymorphism is associated with accelerated HIV-1 disease progression. AIDS 23: 297-307 [PMID:19114863]

83. Ohashi K, Burkart V, Flohé S and Kolb H. (2000) Cutting edge: heat shock protein 60 is a putative endogenous ligand of the toll-like receptor-4 complex. J Immunol 164: 558-61 [PMID:10623794]

84. Oosting M, Cheng SC, Bolscher JM, Vestering-Stenger R, Plantinga TS, Verschueren IC, Arts P, Garritsen A, van Eenennaam H and Sturm P et al.. (2014) Human TLR10 is an anti-inflammatory pattern-recognition receptor. Proc Natl Acad Sci USA 111: E4478-84 [PMID:25288745]

85. Pan Y, Wang Y, Xu J, Wu J, Chen Q, Zeng G and Zhao G. (2017) TG and VLDL cholesterol 
activate NLRP1 inflammasome by Nuclear Factor-kB in endothelial cells. Int J Cardiol 234: 103 [PMID:28062143]

86. Park BS, Song DH, Kim HM, Choi BS, Lee H and Lee JO. (2009) The structural basis of lipopolysaccharide recognition by the TLR4-MD-2 complex. Nature 458: 1191-5 [PMID:19252480]

87. Peri F and Calabrese V. (2014) Toll-like receptor 4 (TLR4) modulation by synthetic and natural compounds: an update. J Med Chem 57: 3612-22 [PMID:24188011]

88. Place DE and Kanneganti TD. (2018) Recent advances in inflammasome biology. Curr Opin Immunol 50: 32-38 [PMID:29128729]

89. Plantinga TS, Johnson MD, Scott WK, van de Vosse E, Velez Edwards DR, Smith PB, Alexander BD, Yang JC, Kremer D and Laird GM et al.. (2012) Toll-like receptor 1 polymorphisms increase susceptibility to candidemia. J Infect Dis 205: 934-43 [PMID:22301633]

90. Poltorak A, He X, Smirnova I, Liu MY, Van Huffel C, Du X, Birdwell D, Alejos E, Silva M and Galanos C et al.. (1998) Defective LPS signaling in C3H/HeJ and C57BL/10ScCr mice: mutations in Tlr4 gene. Science 282: 2085-8 [PMID:9851930]

91. Sabbah A, Chang TH, Harnack R, Frohlich V, Tominaga K, Dube PH, Xiang Y and Bose S. (2009) Activation of innate immune antiviral responses by Nod2. Nat Immunol 10: 1073-80 [PMID:19701189]

92. Salunke DB, Yoo E, Shukla NM, Balakrishna R, Malladi SS, Serafin KJ, Day VW, Wang X and David SA. (2012) Structure-activity relationships in human Toll-like receptor 8-active 2,3diamino-furo[2,3-c]pyridines. J Med Chem 55: 8137-51 [PMID:22924757]

93. Saresella M, La Rosa F, Piancone F, Zoppis M, Marventano I, Calabrese E, Rainone V, Nemni R, Mancuso R and Clerici M. (2016) The NLRP3 and NLRP1 inflammasomes are activated in Alzheimer's disease. Mol Neurodegener 11: 23 [PMID:26939933]

94. Scholl T, Mahanta SK and Strominger JL. (1997) Specific complex formation between the type II bare lymphocyte syndrome-associated transactivators CIITA and RFX5. Proc Natl Acad Sci USA 94: 6330-4 [PMID:9177217]

95. Schroder K and Tschopp J. (2010) The inflammasomes. Cell 140: 821-32 [PMID:20303873]

96. Schwandner R, Dziarski R, Wesche H, Rothe M and Kirschning CJ. (1999) Peptidoglycan- and lipoteichoic acid-induced cell activation is mediated by toll-like receptor 2. J Biol Chem 274: 17406-9 [PMID:10364168]

97. Sharma N and Jha S. (2016) NLR-regulated pathways in cancer: opportunities and obstacles for therapeutic interventions. Cell Mol Life Sci 73: 1741-64 [PMID:26708292]

98. Sherer BA and Brugger N. (2017) Polycyclic tlr7/8 antagonists and use thereof in the treatment of immune disorders Patent number: WO2017106607A1.

99. Shimazu R, Akashi S, Ogata H, Nagai Y, Fukudome K, Miyake K and Kimoto M. (1999) MD-2, a molecule that confers lipopolysaccharide responsiveness on Toll-like receptor 4.J Exp Med 189: 1777-82 [PMID:10359581]

100. Souyris M, Cenac C, Azar P, Daviaud D, Canivet A, Grunenwald S, Pienkowski C, Chaumeil J, Mejía JE and Guéry JC. (2018) TLR7 escapes X chromosome inactivation in immune cells. Sci Immunol 3 [PMID:29374079]

101. Souyris M, Mejía JE, Chaumeil J and Guéry JC. (2019) Female predisposition to TLR7-driven autoimmunity: gene dosage and the escape from $\mathrm{X}$ chromosome inactivation. Semin Immunopathol 41: 153-164 [PMID:30276444]

102. Stöver AG, Da Silva Correia J, Evans JT, Cluff CW, Elliott MW, Jeffery EW, Johnson DA, Lacy MJ, Baldridge JR and Probst P et al.. (2004) Structure-activity relationship of synthetic toll-like receptor 4 agonists. J Biol Chem 279: 4440-9 [PMID:14570885]

103. Sönmez HE and Özen S. (2017) A clinical update on inflammasomopathies. Int Immunol 29: 393400 [PMID:28387826]

104. Takeuchi O and Akira S. (2010) Pattern recognition receptors and inflammation. Cell 140: 80520 [PMID:20303872]

105. Takeuchi O, Kawai T, Mühlradt PF, Morr M, Radolf JD, Zychlinsky A, Takeda K and Akira S. (2001) Discrimination of bacterial lipoproteins by Toll-like receptor 6. Int Immunol 13: 933-40 [PMID:11431423]

106. Takeuchi O, Sato S, Horiuchi T, Hoshino K, Takeda K, Dong Z, Modlin RL and Akira S. (2002) Cutting edge: role of Toll-like receptor 1 in mediating immune response to microbial lipoproteins. J Immunol 169: 10-4 [PMID:12077222]

107. Tarafdar A, Hopcroft LE, Gallipoli P, Pellicano F, Cassels J, Hair A, Korfi K, Jørgensen HG, Vetrie D and Holyoake TL et al.. (2017) CML cells actively evade host immune surveillance through cytokine-mediated downregulation of MHC-II expression. Blood 129: 199-208 [PMID:27793879]

108. Ting JP, Lovering RC, Alnemri ES, Bertin J, Boss JM, Davis BK, Flavell RA, Girardin SE, Godzik A and Harton JA et al.. (2008) The NLR gene family: a standard nomenclature. Immunity 28: 285-7 [PMID:18341998]

109. Tschopp J, Martinon F and Burns K. (2003) NALPs: a novel protein family involved in inflammation. Nat Rev Mol Cell Biol 4: 95-104 [PMID:12563287] 
110. Uematsu S and Akira S. (2008) Toll-Like receptors (TLRs) and their ligands. Handb Exp Pharmacol: 1-20 [PMID:18071652]

111. van der Made CI, Simons A, Schuurs-Hoeijmakers J, van den Heuvel G, Mantere T, Kersten S, van Deuren RC, Steehouwer M, van Reijmersdal SV and Jaeger M et al.. (2020) Presence of Genetic Variants Among Young Men With Severe COVID-19. JAMA [PMID:32706371]

112. Wang W, Wang C, Gong Y and Zhang X. (2018) Inhibition of NLRP1 inflammasome might be a novel therapeutic target in the treatment of peripheral arterial disease. Int J Cardiol 256: 29 [PMID:29454409]

113. Wang Y, Su L, Morin MD, Jones BT, Whitby LR, Surakattula MM, Huang H, Shi H, Choi JH and Wang KW et al.. (2016) TLR4/MD-2 activation by a synthetic agonist with no similarity to LPS. Proc Natl Acad Sci USA 113: E884-93 [PMID:26831104]

114. Westerveld GH, Korver CM, van Pelt AM, Leschot NJ, van der Veen F, Repping S and Lombardi MP. (2006) Mutations in the testis-specific NALP14 gene in men suffering from spermatogenic failure. Hum Reprod 21: 3178-84 [PMID:16931801]

115. Yau AC, Piehl F, Olsson T and Holmdahl R. (2017) Effects of C2ta genetic polymorphisms on MHC class II expression and autoimmune diseases. Immunology 150: 408-417 [PMID:27861821]

116. Yoshimura A, Lien E, Ingalls RR, Tuomanen E, Dziarski R and Golenbock D. (1999) Cutting edge: recognition of Gram-positive bacterial cell wall components by the innate immune system occurs via Toll-like receptor 2. J Immunol 163: 1-5 [PMID:10384090]

117. Youm YH, Nguyen KY, Grant RW, Goldberg EL, Bodogai M, Kim D, D'Agostino D, Planavsky N, Lupfer C and Kanneganti TD et al.. (2015) The ketone metabolite $\beta$-hydroxybutyrate blocks NLRP3 inflammasome-mediated inflammatory disease. Nat Med 21: 263-9 [PMID:25686106]

118. Yu CH, Moecking J, Geyer M and Masters SL. (2018) Mechanisms of NLRP1-Mediated Autoinflammatory Disease in Humans and Mice. J Mol Biol 430: 142-152 [PMID:28733143]

119. Zhai Z, Liu W, Kaur M, Luo Y, Domenico J, Samson JM, Shellman YG, Norris DA, Dinarello CA and Spritz RA et al.. (2017) NLRP1 promotes tumor growth by enhancing inflammasome activation and suppressing apoptosis in metastatic melanoma. Oncogene 36: 3820-3830 [PMID:28263976]

120. Zhang L, Mo J, Swanson KV, Wen H, Petrucelli A, Gregory SM, Zhang Z, Schneider M, Jiang Y and Fitzgerald KA et al.. (2014) NLRC3, a member of the NLR family of proteins, is a negative regulator of innate immune signaling induced by the DNA sensor STING. Immunity 40: 329-41 [PMID:24560620]

121. Zhang S, Hu Z, Tanji H, Jiang S, Das N, Li J, Sakaniwa K, Jin J, Bian Y and Ohto U et al.. (2018) Small-molecule inhibition of TLR8 through stabilization of its resting state. Nat Chem Biol 14: 58-64 [PMID:29155428]

122. Zhong FL, Mamaï O, Sborgi L, Boussofara L, Hopkins R, Robinson K, Szeverényi I, Takeichi T, Balaji R and Lau A et al.. (2016) Germline NLRP1 Mutations Cause Skin Inflammatory and Cancer Susceptibility Syndromes via Inflammasome Activation. Cell 167: 187-202.e17 [PMID:27662089] 